\title{
Ultraviolet-B radiation and nitrogen effects on growth and yield of maize under Mediterranean field conditions
}

Carlos M. Correia $^{\mathrm{a} *}$, João F. Coutinho ${ }^{\mathrm{b}}$, Lars Olof Björn ${ }^{\mathrm{c}}$, José M.G. Torres-Pereira ${ }^{\mathrm{a}}$

${ }^{a}$ Department of Biological and Environmental Engineering, ICETA-University of Trásos-Montes and Alto Douro, Apartado 202, 5000 Vila Real, Portugal ${ }^{\mathrm{b}}$ Department of Soil Science, University of Tra ` s-os-Montes and Alto Douro, Apartado 202, 5000 Vila Real, Portugal ${ }^{\mathrm{c}}$ Department of Plant Physiology, Lund University, Lund, Sweden

*Corresponding author. Tel.: +35-1593-502-35; fax: +35-1593-504-80.

E-mail address: ccorreia@utad.pt

\begin{abstract}
The effects of an increase in UV-B radiation on growth and yield of maize (Zea mays L.) were investigated at four levels of applied nitrogen $\left(0,100,200\right.$ and $300 \mathrm{~kg} \mathrm{ha}^{-} 1$ of N) under Mediterranean field conditions. The experiment simulated a 20\% stratospheric ozone depletion over Portugal. Enhanced UV-B and N deficiency decreased yield and total biomass production by $22-49 \%$. High UV-B dose reduced yield, total biomass and growth of $\mathrm{N}$-fertilized maize plants but did not affect $\mathrm{N}$-stressed plants to the same extent. The response of grain yield to $\mathrm{N}$ was smaller with enhanced UV-B radiation. The underlying mechanisms for these results are discussed.
\end{abstract}

Keywords: Maize; Nitrogen; UV-B radiation

\section{Introduction}

During the past two decades significant reductions in the stratospheric ozone layer, caused by contamination with man-made chlorofluorocarbons, nitrogen oxides and methyl bromide, have occurred over much of the Earth, including temperate latitudes of the Northern Hemisphere, and it is expected that this reduction will increase in magnitude into the next century (WMO, 1995). As a consequence, increased levels of ultraviolet-B (UV-B) radiation have been measured in both hemispheres (Madronich and DeGruijl, 1994; Seckmeyer et al., 1994).

Although UV-B represents only a small part of the solar radiation reaching the surface 
of the Earth, its impact on the biological processes can be very important. UV-B radiation is known to negatively influence plant growth and development in some higher plants (Teramura, 1983; Caldwell et al., 1995; UNEP, 1998), but can, in some cases, stimulate plant growth and development (Sullivan et al., 1992; Tosserams and Rozema, 1995). The response of plants to changes in UV-B levels depends upon concomitant stresses, such as light, temperature, ozone, metals, drought and nutrient limitations (Tevini, 1994; UNEP, 1998). Although nitrogen ( $\mathrm{N}$ ) is a major limiting factor to plant growth and yield, interactive effects of increased UV-B and N nutrition have not been fully studied. In the present study, we hypothesized that UV-B damage to a sensitive species depends on its nitrogen status. We used maize with a high sensitivity to N and UV-B (Santos et al., 1993; Mark and Tevini, 1996, 1997; Mark et al., 1996; Correia et al., 1998) to test this hypothesis under Mediterranean field conditions.

\section{Material and methods}

The experiment was conducted at the University of Trás-os-Montes and Alto Douro, Vila Real, Portugal (41 $11^{\circ} \mathrm{N}, 7^{\circ} \quad 44^{\prime} \mathrm{W} ; 450$ m elevation), between 12 June (sowing date) and 13 October 1998 (final harvest). The experimental design was a factorial arrangement in randomized complete blocks with three replicates. Each plot (8.25 m x 2 m) included three 'useful lines', each limited by two border lines. The first 'useful line' was consigned to the silking ( $50 \%$ of plants with emerged silks) harvest, the second to the physiological and biochemical studies (data not shown in this paper) and the third to the final harvest. The treatments consisted of two UV-B radiation levels [high UV-B treatment ( UV ) and ambient UV-B treatment (C )] combined with four nitrogen levels [0 (N0), $100(\mathrm{~N} 1), 200(\mathrm{~N} 2)$ and $\left.300 \mathrm{~kg} \mathrm{ha}^{-1}(\mathrm{~N} 3)\right]$ of N. Nitrogen fertilizer was applied as urea.

High UV-B treatment was applied using pre-burned Philips sun lamps (TL 40W/12), and began immediately after the plants emerged. Radiation emitted by the UV tubes was filtered using $0.1 \mathrm{~mm}$ cellulose acetate foil (Ultraphan, Weil am Rhein, Germany), which eliminates radiation below $290 \mathrm{~nm}$. The filters were replaced twice a week to maintain uniform optical properties. Lamps were in frames that were adjusted weekly to maintain the UV-B levels on the canopy during the course of the experiment. The experiment 
simulated a 20\% stratospheric ozone reduction in Vila Real (Portugal). Biologically effective UV-B ( UV-B ${ }_{\mathrm{BE}}$ ) doses were based on calculations by Björn and Murphy (1985) using the generalized plant action spectrum, normalized at $300 \mathrm{~nm}$ (Caldwell, 1971) in accordance with the mathematical function elaborated by Thimijan et al. (1978). On the summer solstice with clear sky conditions the supplemental UV-B $B_{\mathrm{BE}}$ dose was $3.16 \mathrm{~kJ} \mathrm{~m}^{-2}$ day $^{-1}$ in addition to the effective $6.84 \mathrm{~kJ} \mathrm{~m}^{-2}$ day $^{-1} \mathrm{UV}-\mathrm{B}_{\mathrm{BE}}$ from the sky. UV-B radiation was supplemented for $8 \mathrm{~h}$ daily. The homogeneity of the UV-B irradiance from the lamps was measured after sunset (i.e. in the absence of ambient UV-B radiation) with an IL 1400A radiometer (International Light Inc., Newburyport, USA) with a photodetector (SEL 240). The spectral sensitivity of the radiometer and the corresponding correction factor were previously determined with an OL754 spectroradiometer (Optronic, Orlando, USA). The high UV-B treatment was suspended on cloudy days to prevent abnormally high UV-B to photosynthetically active radiation (PAR) ratios. Above the control treatment area, non-burning UV-B lamps were used to create shade, as in the UV-B radiated experimental groups. In this way, the visible light environment under control and UV-B frames was similar. Shading from the lamps and lamp supports was estimated with a ceptometer (Decagon Sunfleck Ceptometer, Pullman, WA, USA). During a clear day, with maximum shading (i.e. with low zenith angle), the plant tops received about $90 \%$ of the PAR found above the frames. Less shading is expected with increased zenith angle. With this system a small increase in UV-A radiation under the UV-B frames was observed. The daily integrated percent increase in UV-A was around 2\%. However, under the high PAR levels in the field, the additional UV-A irradiances would be considered neutral in effect and their careful control unnecessary (Middleton and Teramura, 1994).

The yellow hybrid DeKalb 502 was used. Triticale was grown on the site until 2 months before sowing to reduce the level of soil-available N. After triticale was removed, the land was prepared by conventional tillage. Based on soil analyses, $90 \mathrm{~kg} \mathrm{ha}^{-1}$ of $\mathrm{P}_{2} \mathrm{O}_{5}$ as superphospate and $180 \mathrm{~kg} \mathrm{~K}_{2} \mathrm{O}$ as potassium chloride were applied broadcast and 
Table 1

Effects of UV-B radiation and nitrogen supply on morphological characteristics measured at final harvesta

\begin{tabular}{lclllll}
\hline Nitrogen & Radiation & $\begin{array}{l}\text { LAI } \\
\left(\mathrm{m}^{2} \mathrm{~m}^{-2}\right)\end{array}$ & $\begin{array}{l}\text { Average leaf size } \\
\left(\mathrm{cm}^{2}\right)\end{array}$ & NL & NGLBE & $\begin{array}{l}\text { Plant height } \\
(\mathrm{cm})\end{array}$ \\
\hline N0 & UV & $2.79 \mathrm{e}$ & $282.4 \mathrm{~d}$ & 11.1 & $2.7 \mathrm{~d}$ & $220.0 \mathrm{~d}$ \\
& $\mathrm{C}$ & $3.07 \mathrm{de}$ & $291.1 \mathrm{~cd}$ & 11.8 & $3.2 \mathrm{bcd}$ & $229.2 \mathrm{~cd}$ \\
$\mathrm{~N} 1$ & $\mathrm{Mean}$ & $2.93 \mathrm{D}$ & $286.8 \mathrm{C}$ & 11.5 & $2.9 \mathrm{~B}$ & $224.6 \mathrm{D}$ \\
& $\mathrm{UV}$ & $3.18 \mathrm{~d}$ & $315.6 \mathrm{bc}$ & 11.3 & $2.7 \mathrm{~d}$ & $232.5 \mathrm{c}$ \\
& $\mathrm{C}$ & $3.58 \mathrm{c}$ & $341.3 \mathrm{~b}$ & 11.8 & $3.5 \mathrm{abc}$ & $243.0 \mathrm{~b}$ \\
$\mathrm{~N} 2$ & $\mathrm{Mean}$ & $3.38 \mathrm{C}$ & $328.5 \mathrm{~B}$ & 11.6 & $3.1 \mathrm{AB}$ & $237.7 \mathrm{C}$ \\
& $\mathrm{UV}$ & $3.38 \mathrm{~cd}$ & $318.6 \mathrm{bc}$ & 12.0 & $3.0 \mathrm{~cd}$ & $245.0 \mathrm{~b}$ \\
& $\mathrm{C}$ & $4.15 \mathrm{~b}$ & $391.9 \mathrm{a}$ & 11.9 & $3.9 \mathrm{a}$ & $248.5 \mathrm{~b}$ \\
& $\mathrm{Mean}$ & $3.77 \mathrm{~B}$ & $355.3 \mathrm{~A}$ & 11.9 & $3.4 \mathrm{AB}$ & $246.8 \mathrm{~B}$ \\
& $\mathrm{UV}$ & $3.61 \mathrm{c}$ & $348.1 \mathrm{~b}$ & 11.7 & $3.3 \mathrm{abc}$ & $251.7 \mathrm{ab}$ \\
& $\mathrm{C}$ & $4.59 \mathrm{a}$ & $408.1 \mathrm{a}$ & 12.6 & $3.7 \mathrm{ab}$ & $259.4 \mathrm{a}$ \\
& Mean & $4.10 \mathrm{~A}$ & $378.1 \mathrm{~A}$ & 12.2 & $3.5 \mathrm{~A}$ & $255.6 \mathrm{~A}$
\end{tabular}

Analysis of variance

Radiation

Nitrogen
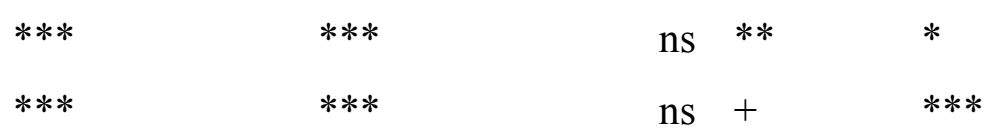

Interaction

ns

ns

ns ns ns

a Significance of main effects: ns, not significant; $+P<0.1 ; * P<0.05 ; * * P<0.01$; *** $P<0.001$. Means within a column followed by the same letter (capital letters for $\mathrm{N}$ effects) were not significantly different at the $90 \%$ significance level.

incorporated prior to sowing. Half of the $\mathrm{N}$ was applied broadcast before sowing, and the remainder was sidedressed as a band when plants reached a height of 40-50 cm. Maize was oversown at a within-row spacing of $0.15 \mathrm{~m}$ spaced $0.75 \mathrm{~m}$ apart, and thinned to a final density of 8.9 plants $\mathrm{m}^{-2}$. Rainfall was supplemented with furrow irrigation as necessary to ensure that the crop did not suffer water stress. Weeds were controlled manually.

At the end of the experiment (16 weeks after emergence), the five central plants from 
the 'useful line' were harvested and the following parameters were evaluated: leaf area index (LAI) (LICOR 3100, Lincoln, NE, USA), number of total green leaves (NL), number of green leaves below the ear (NGLBE) (green leaf area above 50\%), ear length, ear perimeter at mid length, ear water content, grain number, plant height, and dry weight of each aboveground plant organ (after drying in a force-draft oven at $70^{\circ} \mathrm{C}$ to a constant weight). Based on the data for leaf area and dry weight at silking harvest and at final harvest, the mean net assimilation rate (NAR), leaf area ratio (LAR), specific leaf area (SLA) and leaf weight ratio (LWR) were calculated using the equations shown in Hunt (1978).

A UV-B sensitivity index (SI) (Lydon et al., 1986) was determined by adding the percentage changes in plant dry weight, plant height and LAI [percentage change $=($ control UV-B-high UV-B $) /$ control UV-Bx100]. Using this combined response, and according to Correia et al. (1998), treatments with a UV-B SI less than -40 were considered as sensitive, whereas those with an index value between -20 and -40 were considered to be of intermediate sensitivity.

All data were analyzed by analysis of variance to test the main effects of UV-B radiation and nitrogen supply. Significantly different means were separated using the Fisher LSD test.

\section{Results}

\section{1. $U V-B$ effects}

Increased UV-B significantly reduced growth and yield of maize (Fig. 1, Table 1). Grain yield was reduced by 22 (N0) to 33\% (N3). Total aboveground plant biomass was similarly reduced, so harvest index was not affected by increased UV-B. 

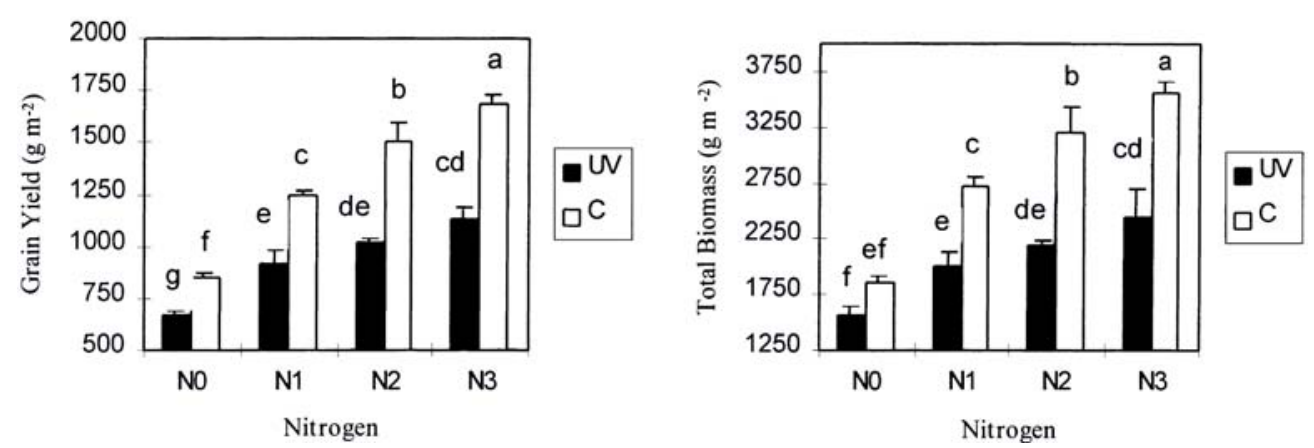

Fig. 1. Effects of UV-B radiation and nitrogen supply on maize dry weight production: (A) grain yield; ( B) total plant biomass. Mean values with standard errors. Bars with the same letters were not significantly different according to an LSD test at $P=0.1$.

Morphological measurements (Table 1) revealed a significant reduction in the leaf area index of UV-B treated plants. This was caused by the reduction of the size of the leaves. Plant height and the NGLBE decreased with enhanced UV-B radiation. Silking was delayed by 1-2 days by high UV-B. Ultraviolet-B affected yield components. Both grain number and grain size were lower under supplemental UV-B (Table 3). Similarly, ear length and ear perimeter were decreased by high UV-B (Table 3).

Growth analysis also revealed significant reduction in NAR, but at the same time a noticeable increase in LAR, by enhanced UV-B, due to an increase in SLA (Table 4). The biomass allocation to leaves (LWR) was unaffected by UV-B radiation.

\subsection{Nitrogen effects}

Grain yield and total aboveground plant biomass increased with increasing $\mathrm{N}$ application (Fig. 1). Grain yield increased from 667 to $1126 \mathrm{~g} \mathrm{~m}^{-2}$ in high UV-B and from 854 to $1683 \mathrm{~g} \mathrm{~m}^{-2}$ in ambient UV-B as N supply increased. There was no significant response to $\mathrm{N}$ supply above $100 \mathrm{~kg} \mathrm{ha}^{-1}$ of $\mathrm{N}$ under high $\mathrm{UV}-\mathrm{B}$, or above $200 \mathrm{~kg} \mathrm{ha}^{-1}$ of $\mathrm{N}$ under ambient UV-B levels. Total plant biomass increased to a similar extent as grain yield, with increases of 57\% in high UV-B and 92\% in ambient UV-B as N supply increased. As a result $\mathrm{N}$ did not significantly affect harvest index.

There was a significant reduction in LAI, plant height and the NGLBE of N-starved plants (Table 1). The reduced LAI was a result of a decrease in individual leaf size, 
whereas the final number of leaves was not affected by $\mathrm{N}$ (Table 1).

Nitrogen deficiency caused a delay in crop phenology, as reflected by silking date (Table 2). Reduced grain yield with low $\mathrm{N}$ application was associated with reduced ear length, ear perimeter, grain number and grain size (Table 3).

Growth analysis revealed higher NAR and, at the same time, lower LAR with increasing N supply due to a lower SLA. Nitrogen-stressed plants had a higher LWR compared with the other N-treatments (Table 4).

Table 2 Effects of UV-B radiation and nitrogen supply on silking date (days after emergence)

\begin{tabular}{lcr} 
Nitrogen & Radiation & Silking \\
\hline N0 & UV & 63 \\
& C & 61 \\
N1 & UV & 59 \\
& C & 58 \\
N2 & UV & 57 \\
& C & 56 \\
N3 & UV & 56 \\
& C & 55
\end{tabular}


Table 3 Effects of UV-B radiation and nitrogen supply on ear and grain characteristics.

\begin{tabular}{|c|c|c|c|c|c|}
\hline Nitrogen & Radiation & $\begin{array}{c}\text { Ear length } \\
\text { (cm) }\end{array}$ & $\begin{array}{c}\text { Ear perimeter } \\
\quad(\mathrm{cm})\end{array}$ & $\begin{array}{c}\text { Grain } \\
\text { number }\end{array}$ & $\begin{array}{r}\text { Grain weight } \\
(\mathrm{mg})\end{array}$ \\
\hline \multirow[t]{3}{*}{ N0 } & UV & $19.4 \mathrm{c}$ & $13.9 \mathrm{e}$ & $407.3 \mathrm{c}$ & $184.0 \mathrm{c}$ \\
\hline & $\mathrm{C}$ & $19.6 \mathrm{c}$ & $15.0 \mathrm{~d}$ & $460.4 \mathrm{bc}$ & $207.2 \mathrm{c}$ \\
\hline & Mean & $19.5 \mathrm{~B}$ & $14.4 \mathrm{C}$ & $433.9 \mathrm{~B}$ & $195.6 \mathrm{C}$ \\
\hline \multirow[t]{3}{*}{ N1 } & UV & $21.1 \mathrm{bc}$ & $15.4 \mathrm{~cd}$ & $552.0 \mathrm{~b}$ & $187.4 \mathrm{c}$ \\
\hline & $\mathrm{C}$ & $22.7 \mathrm{ab}$ & $16.4 \mathrm{ab}$ & $594.7 \mathrm{~b}$ & $234.4 \mathrm{~b}$ \\
\hline & Mean & $21.9 \mathrm{~A}$ & $15.9 \mathrm{~B}$ & $573.3 \mathrm{~A}$ & $210.9 \mathrm{BC}$ \\
\hline \multirow[t]{3}{*}{$\mathrm{N} 2$} & UV & $21.3 \mathrm{bc}$ & $15.4 \mathrm{~cd}$ & $554.7 \mathrm{~b}$ & $206.1 \mathrm{c}$ \\
\hline & $\mathrm{C}$ & $23.3 \mathrm{a}$ & $16.5 \mathrm{a}$ & $699.3 \mathrm{a}$ & $244.6 \mathrm{ab}$ \\
\hline & Mean & $22.3 \mathrm{~A}$ & $16.0 \mathrm{AB}$ & $627.0 \mathrm{~A}$ & $225.3 \mathrm{~B}$ \\
\hline \multirow[t]{3}{*}{ N3 } & UV & $21.2 \mathrm{bc}$ & $15.8 \mathrm{bc}$ & $561.0 \mathrm{~b}$ & $225.3 \mathrm{~b}$ \\
\hline & $\mathrm{C}$ & $22.7 \mathrm{ab}$ & $17.0 \mathrm{a}$ & $710.7 \mathrm{a}$ & $268.4 \mathrm{a}$ \\
\hline & Mean & $21.9 \mathrm{~A}$ & $16.4 \mathrm{~A}$ & $635.8 \mathrm{~A}$ & $246.9 \mathrm{~A}$ \\
\hline \multicolumn{6}{|l|}{$\begin{array}{l}\text { Analysis of } \\
\text { variance }\end{array}$} \\
\hline Radiation & & $*$ & $* * *$ & $* *$ & $* * *$ \\
\hline Nitrogen & & $* *$ & $* * *$ & $* * *$ & $* * *$ \\
\hline Interaction & & ns & ns & ns & ns \\
\hline
\end{tabular}

Significance of main effects: ns, not significant, $* P<0.05$, ${ }^{* *} P<0.01$, *** $P<0.001$.

Means within a column followed by the same letter (capital letters for $\mathrm{N}$ effects) were not significantly different at the $90 \%$ significance level

\subsection{Interactive effects}

Interaction between $\mathrm{N}$ and $\mathrm{UV}-\mathrm{B}$ effects was only significant for grain yield and total plant biomass. A similar tendency exists for leaf size $(P<0.1)$ and LAI $(P=0.13)$. UV-B effects tended to be greater at higher $\mathrm{N}$ levels (Fig. 1, Tables 1 and 5). The effects of all other characteristics were additive. 


\section{Discussion}

\section{1. $U V-B$ effects}

UV-B radiation corresponding to a $20 \%$ stratospheric ozone depletion significantly reduced growth and yield of maize, proving the UV-B sensitivity of maize (Santos et al., 1993; Mark and Tevini, 1996, 1997; Mark et al., 1996; Correia et al., 1998). Decreases in LAI, leaf area duration, and in NAR contributed to lower biomass accumulation in UVB-treated plants. The decrease in NAR indicates that UV-B radiation inhibited or disturbed one or several of the processes involved in photosynthesis and carbon assimilation. Several studies have reported that the exposure to UV-B decreased the net photosynthetic rate of crops (Teramura, 1983; Strid et al., 1990; Correia et al., 1999a). This reduction may be closely related to inhibition of photosynthetic enzymes, increases in stomatal and mesophyll resistance and ultrastructural changes in chloroplasts (Brandle et al., 1977; Jordan et al., 1992; He et al., 1994; Greenberg et al., 1997).

Plant height reduction in this study could have been due to photo-oxidative destruction of the phytohormone indole acetic acid followed by lower cell wall extensibility, as demonstrated in sunflower seedlings (Ros and Tevini, 1995). Height differences were more pronounced during the vegetative stage (data not shown), and this agreed with greater sensitivity at the early development stage to UV-B reported by others (Musil and Wand, 1994; Saile-Mark and Tevini, 1997; Correia et al., 1998). Delay of silking may have been due to impact of enhanced UV-B radiation on the biosynthesis of gibberellins (Saile-Mark and Tevini, 1997). 
Table 4 Effects of UV-B radiation and nitrogen supply on growth analysis parameters.

\begin{tabular}{|c|c|c|c|c|c|}
\hline Nitrogen & Radiation & $\begin{array}{c}\text { NAR } \\
\left(\mathrm{g} \mathrm{m}^{-2} \mathrm{~d}^{-1}\right)\end{array}$ & $\begin{array}{c}\text { LAR } \\
\left(\mathrm{m}^{2} \mathrm{~kg}^{-1}\right)\end{array}$ & $\begin{array}{c}\text { LWR } \\
\left(\mathrm{g} \mathrm{kg}^{-1}\right)\end{array}$ & $\begin{array}{l}\text { SLA } \\
\left(\mathrm{m}^{2} \mathrm{~kg}^{-1}\right)\end{array}$ \\
\hline \multirow[t]{3}{*}{ N0 } & UV & $9.3 \mathrm{c}$ & $1.8 \mathrm{a}$ & $103.3 \mathrm{ab}$ & $17.3 \mathrm{a}$ \\
\hline & $\mathrm{C}$ & $9.7 \mathrm{c}$ & $1.7 \mathrm{ab}$ & $106.4 \mathrm{a}$ & $16.1 \mathrm{~b}$ \\
\hline & Mean & $9.5 \mathrm{~B}$ & $1.8 \mathrm{~A}$ & $104.9 \mathrm{~A}$ & $16.7 \mathrm{~A}$ \\
\hline \multirow[t]{3}{*}{ N1 } & UV & $10.2 \mathrm{bc}$ & $1.6 \mathrm{bc}$ & $98.8 \mathrm{abc}$ & $16.1 \mathrm{~b}$ \\
\hline & $\mathrm{C}$ & $11.7 \mathrm{ab}$ & $1.4 \mathrm{~d}$ & $90.2 \mathrm{~d}$ & $14.9 \mathrm{~cd}$ \\
\hline & Mean & $10.9 \mathrm{~A}$ & $1.5 \mathrm{~B}$ & $94.5 \mathrm{~B}$ & $15.5 \mathrm{~B}$ \\
\hline \multirow[t]{3}{*}{$\mathrm{N} 2$} & UV & $10.8 \mathrm{abc}$ & $1.5 \mathrm{c}$ & $94.2 \mathrm{~cd}$ & $16.4 \mathrm{ab}$ \\
\hline & $\mathrm{C}$ & $12.1 \mathrm{a}$ & $1.3 \mathrm{~d}$ & $93.1 \mathrm{~cd}$ & $14.1 \mathrm{~d}$ \\
\hline & Mean & $11.4 \mathrm{~A}$ & $1.4 \mathrm{~B}$ & $93.6 \mathrm{~B}$ & $15.2 \mathrm{BC}$ \\
\hline \multirow[t]{3}{*}{ N3 } & UV & $9.7 \mathrm{c}$ & $1.5 \mathrm{c}$ & $95.9 \mathrm{bcd}$ & $15.5 \mathrm{bc}$ \\
\hline & $\mathrm{C}$ & $12.0 \mathrm{a}$ & $1.3 \mathrm{~d}$ & $93.7 \mathrm{~cd}$ & $13.9 \mathrm{~d}$ \\
\hline & Mean & $10.9 \mathrm{~A}$ & $1.4 \mathrm{~B}$ & $94.8 \mathrm{~B}$ & $14.7 \mathrm{C}$ \\
\hline \multicolumn{6}{|l|}{$\begin{array}{l}\text { Analysis of } \\
\text { variance }\end{array}$} \\
\hline \multicolumn{2}{|l|}{ Radiation } & $*$ & $* * *$ & ns & $* * *$ \\
\hline \multicolumn{2}{|l|}{ Nitrogen } & + & $* * *$ & $*$ & $* *$ \\
\hline \multicolumn{2}{|l|}{ Interaction } & ns & ns & ns & ns \\
\hline \multicolumn{6}{|c|}{ Significance of main effects: ns, not significant, $+P<0.1, * P<0.05, * * P<0.01$, *** } \\
\hline \multicolumn{6}{|c|}{$P<0.001$. Means within a column followed by the same letter (capitals letters for $\mathrm{N}$} \\
\hline
\end{tabular}

The decrease in the NGLBE in UV-B plants indicated an early senescence of older foliage, also observed by other researchers (Teramura and Sullivan, 1987; Naidu et al., 1993). Premature leaf senescence would alter the canopy carbon gain and nutrient relations. When the activity of lower leaves decreases, the supply of carbohydrates to the roots may become limiting (Palmer et al., 1973; Fairey and Daynard, 1978), reducing root activity and absorption of nutrients, namely nitrogen. In addition, $\mathrm{N}$ compounds are translocated and the photosynthetic rate of those leaves decreases. 
Table 5 Ranking of the nitrogen treatments with respect to a UV-B SI. Mean values with standard errors. Means followed by the same letter were not significantly different at the $90 \%$ significance level. The SI was determined by adding the percentage changes in plant dry weight, plant height and LAI due to increase UV-B

Nitrogen index

Intermediate

N0

Sensitive

N1

$\mathrm{N} 2$

N3
Sensitivity

$$
-29.2(2.2) \mathrm{c}
$$

$$
\begin{aligned}
& -41.8(2.9) \mathrm{b} \\
& -50.2(3.3) \mathrm{a} \\
& -55.6(3.4) \mathrm{a}
\end{aligned}
$$

UV-B maize compensated for a lower NAR by increasing LAR and SLA, which suggested that UV-B decreased leaf thickness (Santos et al., 1993; Musil and Wand, 1994; Correia et al., 1999b). This decrease may be important for three reasons: first, because it changes the light profile within individual leaves (Deckmyn and Impens, 1995; Björn et al., 1996); second, because increased SLA has been correlated with decreased photosynthetic rates, contributing to lower relative growth rates (Poorter, 1989); third, because it affects plant/herbivory relationships (more area is devoured of thinner leaves to maintain the same input of leaf volume) (Björn et al., 1996).

Enhanced UV-B reduced the growth and yield more slowly under N-deprivation, which is consistent with the effects of high doses of UV-B on other crop species grown in interaction with nitrogen (Hunt and McNeil, 1998) and phosphate fertilization (Murali and Teramura, 1985). The lower sensitivity of N-starved plants to UV-B radiation may be explained by the lower rate of cell division and not by the adoption of avoidance strategies such as increased leaf thickness. N-stressed plants commonly have smaller leaves and lowered meristematic activity (Rufty et al., 1989). The reduced rate of cell division increases the opportunity for DNA dimers to be repaired before the cell enters 
the DNA synthesis phase of cell division (Leenhouts and Chadwick, 1987).

\subsection{Nitrogen effects}

The increases in grain yield and total plant biomass with increasing $\mathrm{N}$ supply may be attributable to increased light absorption and/or higher NAR. The differences in radiation interception resulted from the production of smaller leaves in the lower $\mathrm{N}$ levels. Leaf expansion is extremely sensitive to $\mathrm{N}$ supply through its effects on cell elongation mediated by changes in cell turgor (Radin and Boyer, 1982) and metabolic activity (Kriedemann, 1986). The reduced NAR in N-starved plants indicated that $\mathrm{N}$ plays an important role in photosynthesis. High correlations are commonly observed between $\mathrm{CO}_{2}$ assimilation rates and leaf $\mathrm{N}$ contents (Dwyer et al., 1995; Reddy et al., 1996). A lower NAR of N-stressed maize, to some extent, compensated for an increased LAR due to both increases of SLA and LWR, indicating altered leaf morphology and altered biomass allocation to the leaves respectively. Grain yield decreased in N-stressed plants also by the reduced number of grains and grain size. These results agree with several other studies done with maize (Muchow, 1988; Tollenaar et al., 1994; Uhart and Andrade, 1995).

The importance of the quantitative relation between maize yield and nitrogen is readily demonstrated. Our study confirms this, but indicates that a new UV-B climate may change the regression between grain yield and nitrogen application. Our data indicate a $1.53 \mathrm{~g} \mathrm{~m}^{-2}$ and $2.76 \mathrm{~g} \mathrm{~m}^{-2}$ yield increase for each $1.0 \mathrm{~kg} \mathrm{ha}^{-1}$ of nitrogen applied in high UV-B and ambient UV-B levels, respectively.

In conclusion, our results indicate that a supplemental dose of UV-B radiation simulating a $20 \%$ decrease of the stratospheric ozone under Mediterranean field conditions will significantly reduce growth, yield and the $\mathrm{N}$ response of maize. This could have important economical and environmental consequences. 


\section{References}

Björn, L.O., Murphy, T.M., 1985. Computer calculation of solar ultraviolet radiation at ground level. Physiol. Veg. 23, 555-561.

Björn, L.O., Callaghan, T.V., Gehrke, C., Gwynn-Jones, D., Holmgren, B., Johanson, U., Sonesson, M., 1996. Effects of enhanced UV-B radiation on subarctic vegetation. In: Woodin, S.J., Marquiss, M. (Eds.), Ecology of Arctic Environments. Blackwell Science, Oxford.

Brandle, J.R., Campbell, W.F., Sisson, W.B., Caldwell, M.M., 1977. Net photosynthesis, electron transport capacity and ultrastructure of Pisum sativum L. exposed to ultraviolet-B radiation. Plant Physiol. 60, 165-168.

Caldwell, M.M., 1971. Solar ultraviolet radiation and the growth and development of higher plants. In: Giese, A.C. (Ed.), Photophysiology vol. 6. Academic Press, New York, pp. 131-177.

Caldwell, M.M., Teramura, A.H., Tevini, M., Bornman, J.F., Björn, L.O., Kulandaivelu, G., 1995. Effects of increased solar ultraviolet radiation on terrestrial plants. Ambio $24,166-173$.

Correia, C.M., Areal, E.L.V., Torres-Pereira, M.S., Torres-Pereira, J.M.G., 1998. Intraspecific variation in sensitivity to ultraviolet-B radiation in maize grown under field conditions. I. Growth and morphological aspects. Field Crops Res. 59, 81-89.

Correia, C.M., Areal, E.L.V., Torres-Pereira, M.S., Torres-Pereira, J.M.G., 1999a. Intraspecific variation in sensitivity to ultraviolet-B radiation in maize grown under field conditions. II. Physiological and biochemical aspects. Field Crops Res. 62, 97 105.

Correia, C.M., Torres-Pereira, M.S., Torres-Pereira, J.M.G., 1999b. Growth, photosynthesis and UV-B absorbing compounds of Portuguese Barbela wheat exposed to ultraviolet-B radiation. Environ. Pollut. 104, 383-388.

Deckmyn, G., Impens, I., 1995. UV-B increases the harvest index of bean (Phaseolus vulgaris L.). Plant Cell Environ. 18, 1426-1433.

Dwyer, L.M., Anderson, A.M., Stewart, D.W., Ma, B.L., Tollenaar, M., 1995. Changes in maize hybrid photosynthetic response to leaf nitrogen, from pre-anthesis to grain fill. Agron. J. 87, 1221-1225. 
Fairey, N.A., Daynard, T.B., 1978. Assimilate distribution and utilizarion in maize. Can. J. Plant Sci. 58, 719-730.

Greenberg, B.M., Wilson, M.I., Huang, X.D., Duxbury, C.L., Gerhardt, K.E., Gensemer, R.W., 1997. The effects of ultraviolet-B radiation on higher plants. In: Wang, W., Gorsuch, J.W., Hughes, J.S. (Eds.), Plants for Environmental Studies. CRC/Lewis, Boca Raton/New York, pp. 1-35.

He, J., Huang, L.K., Whitecross, M.I., 1994. Choroplast ultrastructure changes in Pisum sativum associated with supple

C.M. Correia et al. / European Journal of Agronomy 12 (2000) 117-125 mentary ultraviolet ( UV-B) radiation. Plant Cell Environ. 17, 771-775.

Hunt, J.E., McNeil, D.L., 1998. Nitrogen status affects UV-B sensitivity of cucumber. Aust. J. Plant Physiol. 25, 79-86.

Hunt, R., 1978. Growth analysis of individual plants, Plant Growth Analysis. Edward Arnold, London.

Jordan, B.R., He, J., Chow, W.S., Anderson, J.M., 1992. Changes in mRNA levels and polypeptide subunits of ribulose-1,5-bisphosphate carboxylase in response to supplementary ultraviolet-B radiation. Plant Cell Environ. 15, 91-98.

Kriedemann, P.E., 1986. Stomatal and photosynthetic limitations to leaf growth. Aust. J. Plant Physiol. 13, 15-31.

Leenhouts, H.P., Chadwick, K.H., 1987. Fundamental aspects of the dose effect relationship for ultraviolet radiation. In: Passchier, W.F., Bosnjakovic, B.F.M. ( Eds.), Human Exposure to Ultraviolet Radiation: Risks and Regulations. Elsevier, New York.

Lydon, J., Teramura, A.H., Summers, E.G., 1986. Effects of ultraviolet-B radiation on the growth and productivity of field grown soybean. In: Worrest, R.C., Caldwell, M.M. (Eds.), Stratospheric Ozone Reduction, Solar Ultraviolet Radiation and Plant Life. Springer, Berlin.

Madronich, S., deGruijl, E., 1994. Stratospheric ozone depletion between 1979 and 1992: implications for biologically active ultraviolet-B radiation and non-melanoma skin cancer incidence. Photochem. Photobiol. 59, 541-546.

Mark, U., Tevini, M., 1996. Combination effects of UV-B radiation and temperature on sunflower (Helianthus annuus L., 
cv. Polstar) and maize (Zea mays L., cv. Zenit 2000) seedlings. J. Plant Physiol. 148, 49-56.

Mark, U., Tevini, M., 1997. Effects of solar ultraviolet-B radiation, temperature and $\mathrm{CO}_{2}$ on growth and physiology of sunflower and maize seedlings. Plant Ecol. 128, 224-234.

Mark, U., Saile-Mark, M., Tevini, M., 1996. Effect of solar UVB radiation on growth, flowering and yield of central and southern European maize cultivars (Zea mays L.). Photochem. Photobiol. 64, 457-463.

Middleton, E.M., Teramura, A.H., 1994. Understanding photosynthesis, pigment and growth responses induced by UV-A irradiances. Photochem. Photobiol. 60, 38-45.

Muchow, R.C., 1988. Effect of nitrogen supply on the comparative productivity of maize and sorghum in a semi-arid tropical environment. III. Grain yield and nitrogen accumulation. Field Crops Res. 18, 31-43.

Murali, N.S., Teramura, A.H., 1985. Effects of ultraviolet-B irradiance on soybean. VI. Influence of phosporous nutrition on growth and flavonoid content. Physiol. Plant. 63, 413-416.

Musil, C.F., Wand, S.J.E., 1994. Differential stimulation of an arid-environment winter ephemeral Dimorphotheca pluvialis (L.) Moench by ultraviolet-B radiation under nutrient limitation. Plant Cell Environ. 17, 245-255.

Naidu, S.L., Sullivan, J.H., Teramura, A.H., DeLucia, E.H., 1993. The effects of ultraviolet-B radiation on photosynthesis of different needle age classes in field-grown Loblolly pine. Tree Physiol. 12, 151-162.

Palmer, A.F.E., Heichel, G.H., Musgrave, R.B., 1973. Patterns of translocation, respiratory loss, and redistribution of $14 \mathrm{C}$ in maize labeled after flowering. Crop. Sci. $13,371-376$.

Poorter, H., 1989. Interspecific variation in RGR: on ecological causes and physiological consequences. In: Lambers, H., Cambridge, M.L., Konings, H., Pons, T.L. (Eds.), Causes and Consequences of Variation in Growth Rate and Productivity of Higher Plants. SPB Academic, The Hague, The Netherlands.

Radin, J.W., Boyer, J.S., 1982. Control of leaf expansion by nitrogen nutrition in sunflower plants: role of hydraulic conductivity and turgor. Plant Physiol. 69, 771-775. Reddy, A.R., Reddy, K.R., Padjung, R., Hodges, H.F., 1996. Nitrogen nutrition and 
photosynthesis in leaves of Pima cotton. J. Plant Nutr. 19, 755-770.

Ros, J., Tevini, M., 1995. Interaction of UV-radiation and IAA during growth of seedlings and hypocotyl segments of sunflower. J. Plant Physiol. 146, 295-302.

Rufty, T.W., Mackown, C.T., Huber, C.T., 1989. Effects of altered carbohydrate availability on whole-plant assimilation of ${ }^{15} \mathrm{NO}_{3}$ Plant Physiol. 89, 457-463.

Saile-Mark, M., Tevini, M., 1997. Effects of solar UV-B radiation on growth, flowering and yield of central and southern European bush bean cultivars (Phaseolus vulgaris L.). Plant Ecol. 128, 114-125.

Santos, I., Almeida, J.M., Salema, R., 1993. Plants of Zea mays

L. developed under enhanced UV-B radiation. I. Some ultrastructural and biochemical aspects. J. Plant Physiol. 141, 450-456.

Seckmeyer, G., Mayer, B., Erb, R., Bernhard, G., 1994. UV-B in Germany higher in 1993 than in 1992. Geophys. Res. Lett. 21, 577-580.

Strid, A., Chow, W.S., Anderson, J.M., 1990. Effects of supplementary ultraviolet-B radiation on photosynthesis in Pisum sativum. Biochim. Biophys. Acta 1020, 260-268.

Sullivan, J.H., Teramura, A.H., Ziska, L.H., 1992. Variation in UV-B sensitivity in plants from a 3000 m elevational gradient in Hawaii. Am. J. Bot. 79, 737-743.

Teramura, A.H., 1983. Effects of ultraviolet-B radiation on the growth and yield of crop plants. Physiol. Plant. 58, 415-427.

Teramura, A.H., Sullivan, J.H., 1987. Soybean growth responses to enhanced levels of ultraviolet-B radiation under greenhouse conditions. Am. J. Bot. 74 ( 7), 975-979.

Tevini, M., 1994. Physiological changes in plants related to UV-B radiation: an overview. In: Biggs, R.H., Joyner, M.E.B. ( Eds.), Stratospheric Ozone Depletion/UV-B Radiation in the Biosphere, NATO ASI Series. Springer, Berlin.

Thimijan, R.W., Carns, H.R., Campbell, L.E., 1978. Final Report. Radiation Sources and Related Environmental Control for Biological and Climatic Effects: UV Research (BACER). Unites States Environmental Protection Agency, Washington, DC.

Tollenaar, M., McCullough, D.E., Dwyer, L.M., 1994. Physiological basis of the genetic improvement of corn. In: Slafer, G.A. ( Ed.), Genetic Improvement of Field Crops. Marcel Dekker, New York. Tosserams, M., Rozema, J., 1995. Effects of ultraviolet-B 
radiation ( UV-B) on growth and physiology of the dune grassland species Calamagrostis epigeios. Environ. Pollut. 89, 209-214.

Uhart, S.A., Andrade, F.H., 1995. Nitrogen deficiency in maize: II. Carbon-nitrogen interaction effects on kernel number. Crop Sci. 35, 1384-1389.

WMO, 1995. Scientific Assessment of Ozone Depletion: 1994. and grain yield. Report no. 37.

UNEP, 1998. Effects of increased solar ultraviolet radiation on terrestrial plants, Environmental Effects of Ozone Depletion: 1998 Assessment. United Nations Environmental Protection Agency. 